\title{
Antihyperuricemic Effect of Ethanol Extract of Snake Fruit (Salacca edulis Reinw.) var. Bongkok on Wistar Male Rat
}

\author{
Leni Herliani Afrianti Priyatno ${ }^{1}$, Elin Yulinah Sukandar ${ }^{2}$, Slamet Ibrahim ${ }^{3}$ and I Ketut Adnyana ${ }^{2}$ \\ 1. Food Technology Departement, Pasundan University, Bandung, Indonesia \\ 2. Pharmacology-Clinical Pharmacy, School of Pharmacy, Institute Technology Bandung, Indonesia \\ 3. Pharmaceutical Chemistry Research Group, School of Pharmacy, Institute Technology Bandung, Indonesia
}

Received: October 12, 2011 / Published: May 20, 2012.

\begin{abstract}
The aim of the study was to investigate antihyperuricemic effect of snake fruit (Salacca edulis Reinw.) var. Bongkok Wistar male rates. Antihyperuricemic investigation on Wistar male rats showed that administration of ethanol extract at doses of 200 $\mathrm{mg} / \mathrm{kg}$ bw decreased serum uric acid level significantly compared to control group at hour 6 and $7(P<0.05)$ after inducing with potassium oxonate intraperitoneally simultaneously with uric acid orally. Whereas, administration of ethanol extract at doses of 100 $\mathrm{mg} / \mathrm{kg}$ bw did not decrease serum uric acid level significantly different compared to control group at hour 6 and $7(P<0.05)$. Determination of uric acid level in urine, administration of ethanol extract at a dose of $200 \mathrm{mg} / \mathrm{kg}$ bw, or probenecid as a standard drug, at a dose of $45 \mathrm{mg} / \mathrm{kg}$ bw increased excretion of urine uric acid level significantly different compared to control group in day of $7(P<0.05)$ after inducing with potassium oxonate intraperitoneally simultaneously with uric acid orally. However, increase of uric acid excretion by ethanol extract was lower compared to that of probenecid at a dose of $45 \mathrm{mg} / \mathrm{kg}$ bw. Mechanism of action of the ethanol extract as an antihyperuricemia has been proposed by inhibition of xanthine oxidase and finally decreased the synthesis of uric acid and increased the excretion of urine uric acid level.
\end{abstract}

Key words: Snake fruit var., Bongkok, ethanol extract, antihyperuricemic, probenecid, Wistar male rat.

\section{Introduction}

Snake fruit (Salacca edulis Reinw.) belongs to the class of Salacca originated from Southeast Asia. The fruit was named snake fruit because skin of the fruit is brown and looks like a snake skin. Form of fruit is egglike in shape, it contains three pieces of seeds covered with white flesh. In Indonesia there are many snake fruit cultivars, which is known in Java, Sumatera and other island. There are some varieties of snake fruit such as Manonjaya, Bongkok, Banjarnegara, Condet, Pondoh, Bali, Enrengkang, and Sidempuan. Most of snake fruit have an astringent

Corresponding author: Leni Herliani Afrianti Priyatno, researcher, Ph.D., research field: functional food. E-mail: leni_priyatno@yahoo.com. taste and are not sweet. Snake fruit var. Bongkok from Conggeang, a sub district of Sumedang West Java, is more sour, bitter, stringent and not sweet than the other snake fruit.

Snake fruit (Salacca edulis Reinw.) var. Bongkok, which grows in Sumedang Regency, West Java, contained flavonoid, alkaloid, terpenoid, tannin, and quinon compound groups, whereas saponin was not found [1]. Two compounds, i.e., 3-hydroxystigmastan-5(6)-en ( $\beta$-sitosterol) and pyrolle-2.4-dicarboxylic acid-methylester isolated of snake fruit ethyl acetate extract. The pyrolle-2.4-dicarboxylic acid-methylester isolated from snake fruit var. Bongkok is a new compound [2]. Snake fruit var. Pondoh contains sucrose, glucose, fructose and volatile compounds as methyl esters of 
butanoic acids, 2-methylbutanoic acid, hexanoic acid, pentanoic acid and carboxylic acids [3].

Compounds of $\beta$-sitosterol and pyrolle-2.4-dicarboxylic acid-methylester can be seen in Figs. 1 and 2.

Snake fruit var. Bongkok becomes an unfavorable fruit and wasted product. In 2003, the harvested snake fruit var. Bongkok decreased by $24 \%$, leading to the extinction. In order to overcome this problem, it is needed to gain the additional economic values of the snake fruit var. Bongkok by studying pharmacological effects in vivo test using experimental animal to become medicine or functional food.

Xanthine oxidase (XO) is a flavin enzyme that catalyzes the oxidation of both hypoxanthine and xanthine to uric acid [4]. During the process of purin oxidation by xanthine oxidase, reactive oxygen species such as peroxides generated Xanthine oxidase participates in purine degradation using molecular oxygen as the electron acceptor thereby resulting in production of superoxide anion $\left(\mathrm{O}_{2}{ }^{-}\right)$and hydrogen peroxide $\left(\mathrm{H}_{2} \mathrm{O}_{2}\right)$ [5]. Therefore, $\mathrm{XO}$ inhibitors have

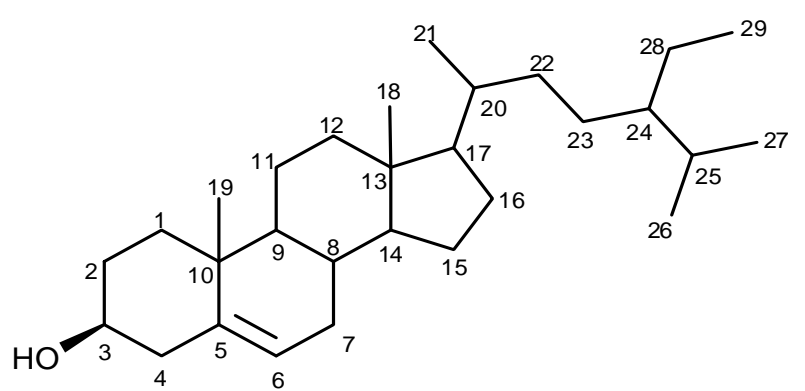

Fig. 1 3-Hydroxystigmastan-5(6)-en ( $\beta$-sitosterol).

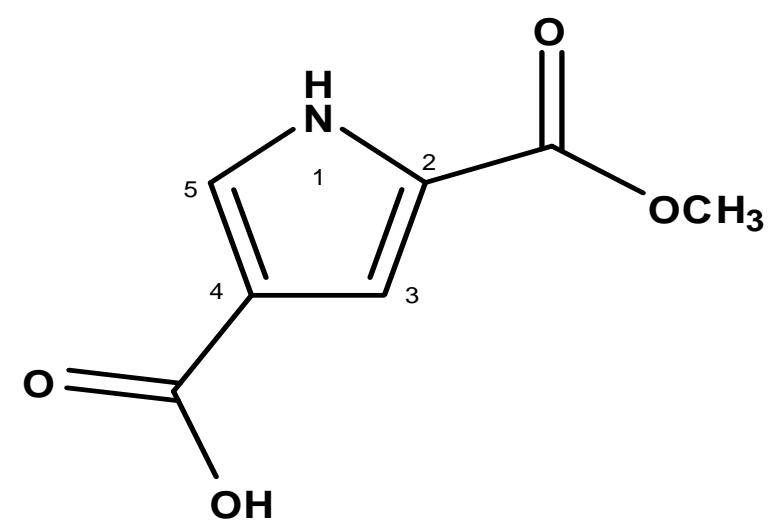

Fig. 2 Pyrolle-2.4-dicarboxylic acid-methylester. been proposed as potential therapeutic agents for treating hyperuricemia as they could be used to block the biosynthesis of uric acid [6]. The aim of the study is to determine antihyperuricemia, as well as to predict mechanism of action of snake fruit (Salacca edulis Reinw.) var. Bongkok.

The composition of the species is very attracted to study, its compound has not been known up to now. High uric acid level in blood known as gout can enhance cardiovascular disorder. Allopurinol is used commercially as anti gout with mechanism of action of xanthine oxidase inhibitors. Allopurinol is indicated when uricosuric drugs fail to reduce serum urate lower than $7.0 \mathrm{mg}$ per $\mathrm{dL}$. Xanthine oxidase catalyzes the oxidation of hypoxanthine and xanthine to uric acid. Xanthine oxidase is a complex metalloflavoprotein [7].

The ethanol extract at concentrations of $0.01,0.02$, $0.2,2$, and $2,000 \mu \mathrm{g} / \mathrm{mL}$ showed xanthin oxidase inhibition by $20.89 \%, 32.78 \%, 44.96 \%, 50.30 \%$, and $50.25 \%$, respectively, with $\mathrm{IC}_{50}$ of $44.95 \mu \mathrm{g} / \mathrm{mL}$. At the same concentrations, the pyrolle-2.4-dicarboxylic acid-methylester showed xanthin oxidase inhibition by $27.7 \%, \quad 30.5 \%, \quad 37.3 \%, \quad 50.27 \%$ and $50.55 \%$ respectively, with $\mathrm{IC}_{50}$ of $48.86 \mu \mathrm{g} / \mathrm{mL}$. Allopurinol as a standard drug showed $\mathrm{IC}_{50}$ of $0.92 \mu \mathrm{g} / \mathrm{mL}$ [2]. Moreover, during the oxidation, free radicals are also generated. Allopurinol (4-hydrxipirazolo [3,4-d] pyrimidin), an analog hypoxanthine, is a specific potent inhibitor for xanthine oxidase, hence decreases blood uric acid level [5]. In this research, it was found that the ethanol extract of snake fruits var. Bongkok showed antioxidant activity decreased serum uric acid level with its mechanism of action similar to which showed xanthin oxidase inhibition in vitro [2].

This paper describes mechanism of action of the ethanol extract of snake fruit var. Bongkok as an antihyperuricemia which has been proposed by inhibition of xanthine oxidase and finally decreased the synthesis of uric acid and increased the excretion of urine uric acid level. This study revealed the existence of antihyperuricemia of snake fruit var. Bongkok. 


\section{Materials and Methods}

\subsection{Plant Material}

The snake fruit (Salacca edulis Reinw.) var. Bongkok was collected from Conggeang, a sub district of Sumedang West Java, Indonesia, and it was weighed, peeled, fractionated into little pieces, and dried at $40{ }^{\circ} \mathrm{C}$ in tunnel drier to constant weight. The dried samples were ground to fine powder by using a grinder. The dried powdered snake fruit (Salacca edulis Reinw.) var. Bongkok (10 g) was macerated in ethanol $(100 \mathrm{~mL})$ and kept in container overnight, then filtered (Whatman No.1 filter paper). The filtrates were evaporated at $40^{\circ} \mathrm{C}$.

\subsection{Animal Model of Hyperuricemia on Male Rat (in vivo)}

Experimetal animal model of hyperuricemia induced by uricase inhibitor potassium oxonate has been used to study [8]. Briefly, male rats were injected intraperitoneally with potassium oxonate $(200 \mathrm{mg} / \mathrm{kg})$ and natrium urate $(15 \mathrm{mg} / \mathrm{kg})$ orally $1 \mathrm{~h}$ before the final drug administration to increase the serum urate level. Whole blood samples were collected from rat by tail vein bleeding. The blood was allowed to clot for approximately $1 \mathrm{~h}$ at room temperature and then centrifuge at $12,000 \mathrm{rpm}$ min to obtain the serum. The serum was stored at $-20{ }^{\circ} \mathrm{C}$ until assayed. Serum uric acid was determined by the phosphotungstic acid methods [9].

\subsection{Drug Administration}

Snake fruit var. Bongkok extract and probenecid at various concentrations were dissolved in $\mathrm{CMC}-\mathrm{Na}$ $0.5 \%$. Suspension volume per dose administered based on body weight of rats.

The extract and positive control (drug) orally for five consecutive days performed on twenty-four male Wistar rats randomly divided into four groups, as the following: control group (CMC 0.5\%); ethanol group (dose $100 \mathrm{mg} / \mathrm{kg} \mathrm{bw}$ ); ethanol group (dose $200 \mathrm{mg} / \mathrm{kg}$ bw); probenecid group (45 mg/kg bw).

Whole blood samples were collected from rat by tail vein bleeding. The blood was allowed to clot for approximately $1 \mathrm{~h}$ at room temperature and then centrifuged at $12,000 \mathrm{rpm}$ for $5 \mathrm{~min}$ to obtain the serum. The serum was stored at $-20{ }^{\circ} \mathrm{C}$ until assayed. Dilute urine $1+10$ with dist. Water, determinate uric acid by the phosphotungstic acid method.

\section{Result and Discussion}

Fig. 3, antihyperuricemic investigation to Wistar male rats showed by administration of ethanol extract at doses $200 \mathrm{mg} / \mathrm{kg}$ bw, decreased serum uric acid level significantly different compared to control group at hour 6 and $7(P<0.05)$ after induced with potassium oxonate intraperitoneally simultaneously with uric acid orally. Whereas, administration of ethanol extract at dose of $100 \mathrm{mg} / \mathrm{kg}$ bw did not decreased serum uric acid level significantly different compared to control group at hour 6 and $7(P<0.05)$. But, probenecid did not decrease serum uric acid level significantly, it is to accelerate the excretion of urine uric acid.

Nguyen and the others [10] have reported inhibitory effect on xanthine oxidase some of medicinal plants in the South of Vietnam such as Artemisia vulgaris (leaf), caesalpinia sappan (wood), Blumea blasamifera (aerial parts) and T. scandens (stem).

The efficacy of Biota orientalis extract and its main flavonoids consist of quercetin and rutin in reducing serum urate levels in mouse model of hyperuricemia induced by the uricase inhibitor potassium oxonate and in vivo inhibiting xanthine oxidase activities in mouse liver [9]. This study is the first to reveal that flavonoids, including Genistein, Apigenin, Quercetin, Rutin and Astilbin, did not show any significant effect on xanthine oxidase activity in vitro, but did have a significant effect on xanthine oxidase activities in vivo. Moreover, serum xanthine oxidase activity was correlated with serum uric acid levels, while no correlation was observed for liver xanthine oxidase activity [11]. 


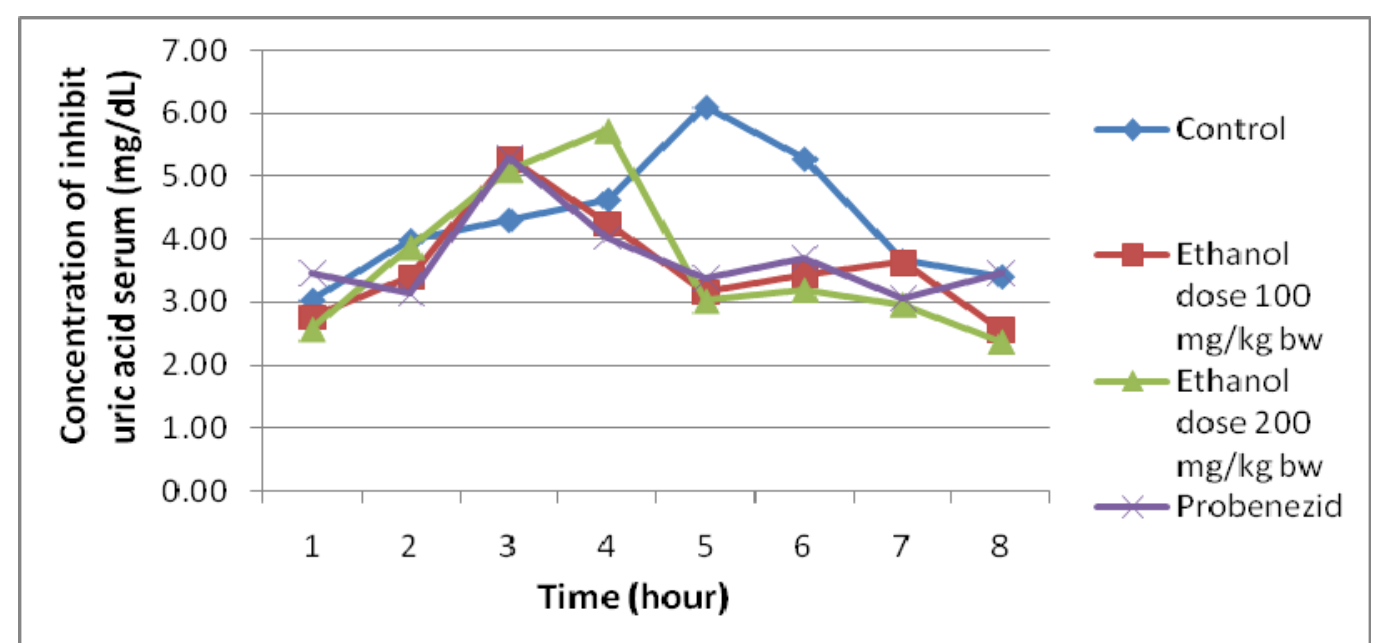

Fig. 3 Antihyperuricemic investigation to Wistar male rats showed by administration of ethanol extract of snake fruit var. Bongkok at doses 100, $200 \mathrm{mg} / \mathrm{kg} \mathrm{Bw}$.

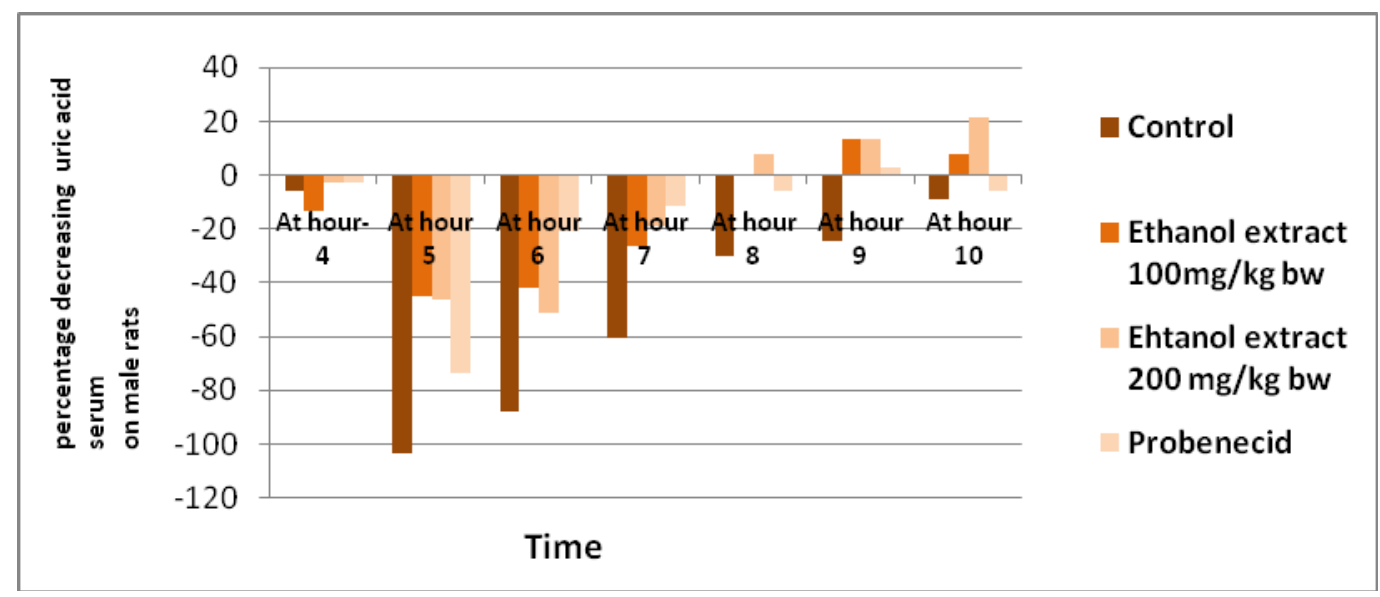

Fig. 4 Percentage of decreasing serum uric acid in male rats.

Fig. 4 shows that, determination of uric acid level in urine, administration of ethanol extract at a dose of $200 \mathrm{mg} / \mathrm{kg}$ bw, or probenecid as a standard drug, at a dose of $45 \mathrm{mg} / \mathrm{kg}$ bw increased excretion of urine uric acid level significantly different compared to control group in day of $7(P<0.05)$ after induced with potassium oxonate intraperitoneally simultaneously with uric acid orally. However, increase of uric acid excretion by ethanol extract was lower compared to that of probenecid at a dose of $45 \mathrm{mg} / \mathrm{kg}$ bw. Probenecid is used as anti gout with mechanism of action to accelerate the excretion of urine uric acid (as uricosuric), it has no effect to decrease uric acid serum.

Fig. 5 shows that determination of uric acid levels in urine indicate that administration of ethanol extract at doses of 100 and $200 \mathrm{mg} / \mathrm{kg}$ bw showed increased excretion of uric acid in urine is lower than the standard drug. Probenecid at a dose of $45 \mathrm{mg} / \mathrm{kg}$ bw increased excretion of urine uric acid level significantly different compared to control group in day of $7(P<0.05)$ after induced with potassium oxonate intraperitoneally simultaneously with uric acid orally.

Mechanism of drug action antihyperuricemia consisted of two types that were inhibit the activity of xanthine oxidase and accelerate the excretion of urine uric acid [11]. Moreover, probenecid increases urine uric acid excretion by inhibition of proximal tubulus reabsorption, hence it reduces serum uric acid level 


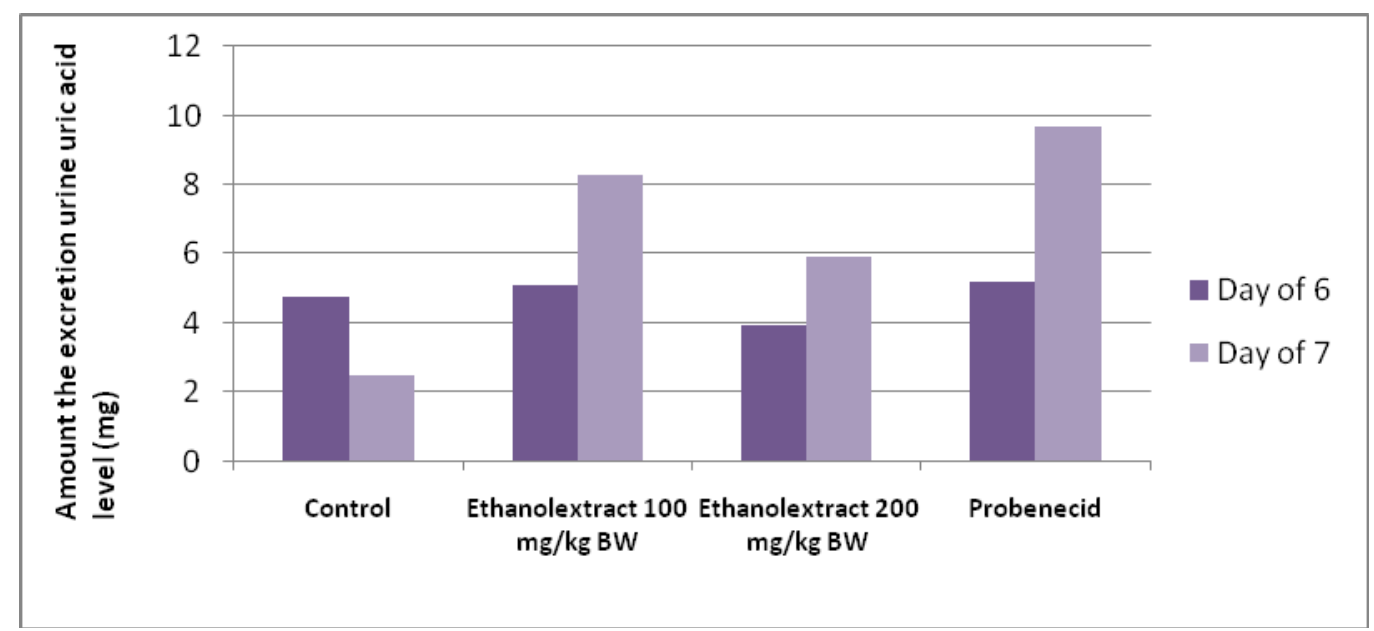

Fig. 5 The excretion of urine uric acid level.

[7]. In this research, it was found that ethanol extract of snake fruit var. Bongkok increased the excretion of urine uric acid level.

This research has discovered the existence of antihyperuricemia in ethanol extract of snake fruit var. Bongkok. Mechanism of action of the ethanol extract as an antihyperuricemia has been proposed to decrease the synthesis of uric acid. Antihyperuricemia mechanism of action of ethanol extract of the uricosuric causes an increase in urinary excretion of uric acid.

The existence of pharmacological active compound from extract of snake fruit (Salacca edulis Reinw.) var. Bongkok can be used as a potential lead compound to develop the extract of snake fruit var. Bongkok as medicine and functional food.

\section{Conclusion}

Mechanism of action of the ethanol extract of snake fruit var.. Bongkok as an antihyperuricemia has been proposed to decrease the synthesis of uric acid and as an uricosuric because of increasing the excretion of urine uric acid.

Further researches can be conducted to develop of antihyperuricemic medicine as well as functional food from extract of snake fruit var.. Bongkok are safety tests and formulation development of the extracts and its active compound.

\section{Acknowledgments}

Author would like to thank the Hibah Kompetitif Batch 2, 2011 for the financial support.

\section{References}

[1] L.H. Afrianti, E.Y. Yulinah, S. Ibrahim, I.K. Adnyana, Inhibisi xanthin oksidase, Ekstrak Daging Buah Salak Varietas Bongkok (Salacca edulis Reinw.), Infomatek 8 (2006) 1-5.

[2] L.H. Afrianti, E.Y. Yulinah, S. Ibrahim, I.K. Adnyana, Xanthine oxidase inhibitor activity of terpenoid and pyrrole compounds isolated from snake fruit (Salacca edulis Reinw.) cv. Bongkok, J. Applied Science 20 (2007) 3127-3130.

[3] S. Supriyadi, M. Suzuki, K. Yoshida, T. Muto, A. Fuujita, Watanabe, Changes in the volatile compounds and in the chemical and physical properties of snake fruit (Salacca edulis Reinw.) cv. Pondoh during maturation, Agric. Chem. 50 (2002) 7627-7633.

[4] I.A. Ramallo, S.A. Zacchino, R.L. Furlan, A rapid TLC autographic method for the detection of xanthine oxidase inhibitors and superoxide scavengers, Phytochem. Anal. 17 (2006) 15-19.

[5] M. Fields, G.L. Charles, D.L. Mark, Allopurinol, an inhibitor of xanthine oxidase, reduces uric acid levels and modifies the signs associated with copper deficiency in rats fed fructose, Free Radical Biol. \& Med. 20 (1996) 595-600.

[6] T. Unno, A. Sugimoto, T. Kakuda, Xanthine oxidase inhibitors from the leaves of Lagerstroemia speciosa (L.), Pers. Ethnopharmacol 93 (2004) 391-395.

[7] H.G. Vogel, H.V. Wolfgang, Drug Discovery and Evaluation Pharmacological Assay, Springer, Philadelphia, 1996, pp. 178-179.

[8] T.M. Al-Qirim, M. Shahwan, K.R. Zaidi, Q. Uddin, N. 
Banu, Effect of khat, its constituent and restraint stress on free radical metabolism of rats, Ethnopharm 83 (2002) 245-250.

[9] Z.X. Zhu. Y. Wang, L.D. Kong, C. Yang, X. Zang, Effect of Biota orientalis extract and its flavonoid constituents, quercetin and rutin on serum uric acid levels in oxonate-induced mice and xanthine dehydrogenase and xanthine oxidase activities in mouse liver, J. Ethnopharmacology 93 (2004) 133-140.
[10] M.T.T. Nguyen, S. Awale, Y. Tezuka, Q.L. Tran, H. Watanabe, S. Kadota, Xathine oxidase inhibitory activity of Vietnamese medicinal plants, J. Biol. Pharm. Bull. 27 (2004) 1414-1421.

[11] J. Huang, S. Wang, M. Zhu, J. Chen, X. Zhu, Effects of genistein, apigenin, quercetin, rutin and astilbin on serum uric acid levels and xanthine oxidase activities in normal and hyperuricemic mice, Food and Chemical Toxicology 49 (2011) 1943-1947. 